\title{
"The Old Government Collapses - the New Is Born...": Dmitry Sverchkov's Literary Works on The St. Petersburg's Soviet of Workers' Deputies of 1905
}

Ilya Nikolaevich Strekalov (Moskva)

\begin{abstract}
This article deals with the literary and publishing activity of Dmitry Sverchkov, a member of the Executive Committee of the Petersburg Soviet of Workers' Deputies, 1905. It is connected with his memory of the creation, activity and termination of the Soviet. Based on archival documents and the published works, it is shown that during the period after the revolutionary events of 1917, Sverchkov sought to keep the memory of the Soviet in works of prose and in cinema. The plots of his script "October Revolution 1905 and the first St. Peterburg's Soviet of Workers 'Deputies" (1924) and his play "But Are Not Defeated!" (1931) are analyzed. The most important point is that the writer shows the people as participants of the revolutionary events in 1905. The article is also based on shorthand reports of Sverckov's speeches at The Vseroskomdram's Plenums.
\end{abstract}

\section{Key words}

Dmitry Fedorovich Sverchkov; St. Petersburg Soviet of Workers' Deputies; the First Russian revolution; working class; the people; literature; drama; cinema; 1905

Абстракт

\section{„Старое правительство“ рухнуло, новое родилось...." Литературные произведения Дмитрия Сверчкова о Петербургском совете рабочих депутатов 1905 года}

\begin{abstract}
Статья посвящена литературной и публицистической деятельности Дмитрия Сверчкова, члена исполнительного комитета Петербургского Совета рабочих депутатов 1905 г. Эта деятельность связана с его памятью о создании, деятельности и поражении Совета. На основе архивных документов и опубликованных работ показывается, что в течение периода, последовавшего за революционными событиями 1917 г., Сверчков стремился сохранить память о Совете посредством прозаических произведений и в кинематографе. Анализируются сюжеты его киносценария «Октябрьская революция 1905 года и первый Санкт-Петербургский Совет рабочих депутатов» (1924 г.) и его пьеса «Но не побеждены!» (1931 г.). Наиболее важным в данном случае представляется то, что писатель показывает народ как участника революционных событий 1905 г. Кроме того, статья написана с привлечением стенографических отчётов речей Д. Ф. Сверчкова на Пленуме Всероскомдрама.
\end{abstract}

I wish to acknowledge the language assistance provided by writer Robert Richardson for my article. 


\section{Ключевые слова}

Дмитрий Фёдорович Сверчков; Санкт-Петербургский Совет рабочих депутатов; Первая русская революция; рабочий класс; народ; литература; драма; кино; 1905.

In the last few years, there has been growing interest in the history of revolutions: their reasons, nature, events and results. This is particularly because of the $100^{\text {th }}$ anniversaries of the February and October Revolutions of 1917. The First Russian Revolution of 19051907 will also be analyzed since it was a major event in Russian history and remained in the memory of its participants for many decades.

Dmitry Fedorovich Sverchkov (Vvedenskii) remembered the First Russian revolution of 1905-1907 as a member of the Executive Committee of the St. Petersburg Soviet of Workers' Deputies, which took place in October - November, 1905. However, in 1938 Sverchkov was shot following a decision of the Supreme Court of the USSR, as a member of the "right" opposition, and, possibly, because of his unstable political views: to begin with, he was close to the Bolsheviks, then to the Mensheviks, and was a friend of Leon Trotsky, writing letters to him. Subsequently, he was forgotten. He was rehabilitated in 1956 with the beginning of Nikita Khrushchev's reign, but in all research works or publications his name was only briefly mentioned. Meanwhile, Sverchkov as a politician overshadowed Sverchkov as a writer. Perhaps this was also because Sverchkov did not state anything about his journalistic and literary activities in his self-written biography ${ }^{1}$. Engaging in public and social activities after 1917, he wrote a memoir titled "The Dawn Of Revolution". It was concerned with the revolutionary events of 1905-1907 and reprinted four times in the 1920s. Sverchkov also took part in such literary organizations as Vseroskomdram and The Russian Association of Proletarian Writers (RAPW) and wrote stories and novels, e.g. "Alexandrit" or "Razgonovy".

So, the article deals with the problem of interpretation of historical events in fiction. The problem is that the events were going in some objective way, but many years later their participants can make its literary interpretation and it will differ - sometimes, very seriously - from was happened in reality. Making the true issues of the historical events in their stories, novels etc., the contributors can change some motives and aspects, increase or reduce the role of participants of events because of changing political and ideological circumstances of the country where this writing is to be published. Notably, this is evident in turning from the tsarist Russia in 1905 to the Soviet Union in the 1920's-1930's. Some aspects and facts are true and objective, and some are reinterpreted or omitted under the ideological policy. This circumstance is to be understood while we are going to examine the fiction which was written, even by the participant of the event (as D. F. Sverchkov was), many years after the times of the described events in other country under other political, economic regime.

1 SVERCHKOV, Dmitry: Autobiography. In: Deyateli SSSR i revolyutsionnogo dvizheniya Rossii. Entsiklopedicheskiy slovar Granat. Moscow: Kniga, 1989, p. 663. 
Previous studies of the literary activity of Dmitry Sverchkov indicate that, unfortunately, analysis of him as a subject is highly fragmented in different research publications and memoirs of contemporaries. It is known that he participated in the discussion, as a representative from the RAPW, of the play "Bath" by the famous poet and playwright Vladimir Mayakovsky. Besides, on the $23^{\text {rd }}$ of September 1929, he presided at the meeting of the artistic-political soviet of the state theater of Vsevolod Meyerhold. Sverchkov urged all of the meeting's participants (there were such writers as Valentin Kataev, Mikhail Zoschenko, Yuri Olesha, and others) to participate actively in the exchange of opinions about the play ${ }^{2}$. Despite Sverchkov's call, the discussion was not very active, however, afterwards and following the favourable opinion of Vs. Meyerhold about the play, Sverchkov as the chair of he discussion stated that "of course, we should welcome 'Bath"'" The resolution of Sverchkov to recommend the play for the theatre was accepted unanimously.

The famous Soviet writer Varlam Shalamov wrote about D. F. Sverchkov in his memoirs, noting that he was in a friendship with the acmeist poet Vladimir Narbut. Narbut was engaged in the publishing business, but at one point was excluded from the ranks of the members of the Communist Party of Bolsheviks, although Sverchkov, according to Shalamov, was a member of the Collegium of the USSR Supreme Court and "helped Narbut to be very active", but in 1937 they were victims of the repressions and subsequently died $^{4}$.

Sverchkov's name appeared in publications after his rehabilitation in 1956. In 1973 there was a short article about Sverchkov's activities in writing scripts for several films ${ }^{5}$. In 1977 there was the publishing of a collection of memoirs, articles and essays about the Chairman of the All-Russian Extraordinary Commission (Cheka) Felix Dzerzhinsky, which also contained the story "On the transport" written by D. F. Sverchkov. In a brief reference before the text, Sverchkov was named as "a member of the Communist party" who had "the responsible work of the people's Commissariat of Railways" in the 1920s ${ }^{6}$. The author narrated the meetings of Dzerzhinsky with railway workers and his work in Siberia during the last years of his life.

The most famous memoir of D. F. Sverchkov "Dawn of the Revolution" was printed in the 1920s in four editions, covering many historical events of Russia at the beginning of the twentieth century. In terms of the First Russian Revolution of 1905-1907 and the Soviets of 1905, these memoirs are of interest for questions relating to the origin of the Soviets (e.g. were they created by the people‘s masses, or were they the "successor" to the different workers' organizations of 1905, such as those that were created by the

2 FEVRALSKY, Alexander: Vstrechi s Mayakovskim. Moscow: Sovetskaya Rossiya, 1971, p. 66.

3 MAYAKOVSKY, Vladimir: Polnoye sobraniye sochineniy. T. 12. Moscow: Goslitizdat, 1959, p. 664.

4 SHALAMOV, Varlam: Vospominaniya. In: SHALAMOV, Varlam: Neskolko moikh zhizney. Vospominaniya. Zapisnyye knizhki. Perepiska. Sledstvennyye dela. Moscow: Eksmo, 2009, p. 44.

5 Sverchkov Dmitriy Fedorovich. In: Stsenaristy sovetskogo khudozhestvennogo kino. 1917-1967. Spravochnik. Moscow: Iskusstvo, 1973, p. 326.

6 SVERCHKOV, Dmitry: On the transport. In: O F. E. Dzerzhinskom. Vospominaniya. Stati. Ocherki sovremennikov. Moscow: Politizdat, 1977, p. 191. 
priest George Gapon, the "okhranka” chief Sergey Zubatov or the senator Nikolas Shidlovsky?), and this is because Sverchkov took part in relevant discussions in the $1920 \mathrm{~s}^{7}$.

Current research on the literary works of Sverchkov is focused on the idea to make these papers available and well-known to the academic community. In particular, there are Sverchkov's works about the history of the Civil war, 1917-1920 in the North Caucasus. According to Aslan Kazanchi, D. F. Sverchkov's memoir is of value because of its description of the situation in Kuban after the 1917 February Revolution, giving information on the activity of the Interim Executive Committee formed there, exploring the Cossacks' position on the results of the February and October Revolutions and reflecting on the relationship of Kuban to all other areas of Russia of that era. Kazanchi notes while citing D. F. Sverchkov's words in the epigraph to the article: "This thinker, certainly, understood with all depth and sharpness the problems facing Russia in that time of troubles, time of the Civil war, 1917-1920"8.

Thus, the analysis of the publications, researches and memoirs connected with the publishing activity of D. F. Sverchkov shows that very few publications can be found in the literature. Although several studies mentioned a few works of Dmitry Sverchkov, there are no complex researches on this subject as an integral way showing separate stages of the creative activity of Sverchkov, including his literary work devoted to the revolutionary events of 1905, such as the existence of the St. Petersburg Soviet of Workers' Deputies, known at that time throughout Russia as a body of revolutionary power. It should be noted that Sverchkov's works can be very useful for researchers because he was a member of the Soviet's Executive Committee and, later, the accountant of it. The aim of this paper is to analyze Dmitry Sverchkov's determination to keep safe the memory of The St. Petersburg's Soviet of Workers' Deputies, which existed in a context of the 1905 revolutionary events; the achievement of this aim is focused on his literary works - the unreleased script for a film called "October revolution 1905 and the First St. Petersburg Soviet of Workers' Deputies" (1924) and the forgotten play "But Are Not Defeated! (1905)" (1931). The first script is available in the Russian State Historical Archive (RSHA, St. Petersburg), the second was published as a book in 1931. The analysis of literary works of Sverchkov about the First Russian Revolution and, in particular, the St. Petersburg Soviet allows recognition of how the author aspired, being a participant of those events, to keep in Soviet Russia (USSR), the new country which was considered the „successor" of the 1905 Soviets, a particular memory of the St. Petersburg Soviet of 1905. This research below can be considered as a contribution to the publicizing of the poorly studied literary activity of D. F. Sverchkov.

7 ALATORTSEVA, Alevtina: Sovetskaya istoricheskaya periodika 1917 - seredina 1930-ih godov. Moscow: Nauka, 1989, p. 168-169.

8 KAZANCHI, Aslan: Grazhdanskaya voyna na Severnom Kavkaze glazami ochevidtsa (Po materialam Tsentra dokumentatsii noveyshey istorii Krasnodarskogo kraya (TsDNIKK)). In: Rossiya glazami memuaristov: Analiz neizvestnykh i maloizvestnykh vospominaniy. Materialy 36-y Vserossiyskoy zaochnoy nauchnoy konferentsii. Saint-Petersburg: Nestor, 2004, p. 216. 
"You understand nothing... We have the Soviet...": Script of the movie "October Revolution of 1905 and St. Petersburg Soviet of Working Deputies" (1924)

In 1924 D. F. Sverchkov's scenario for a film with the title "October Revolution of 1905 and the First St. Petersburg Soviet of Workers 'Deputies" arrived at the Northwest Regional Management for Photography and Cinematography, at the request of the "Sevzapkino" film studio and the screenwriter P.E. Shchegolev. The director of "Sevzapkino", Mikhail Efremov, wrote on the first page of the scenario that the events described are the "continuation of the $9^{\text {th }}$ January 1905". Therefore it would be necessary to return it to Pavel Shchegolev for further examination and consideration ${ }^{9}$. Such an address to Shchegolev is connected with the fact that he was a scriptwriter for the film called "The $9^{\text {th }}$ of January 1905". It was devoted to the execution of demonstrating workers led by the priest Gapon on the $9^{\text {th }}$ of January 1905. This day is well-known in Russian history as "Bloody Sunday". "The $9^{\text {th }}$ of January 1905" was first shown on the $2^{\text {nd }}$ of December 1925 , but as Shchegolev was engaged with this subject, Sverchkov's scenario was given to him.

The structure of the scenario was as follows: 134 scenes united in 9 parts. For example, the second part about the formation of the St. Petersburg Soviet was titled "The old government collapses - the new is born ..." ${ }^{10}$. Scenes show different sketches from the life of the socio-political forces which were most active in 1905: the striking workers at the plants creating their self-organization; the representatives of the intelligentsia who are thinking about their relationship to the tsar's government and their readiness to support it and oppose what they considered to be revolutionary chaos (for example, this can be seen in "a meeting of liberals", the $91^{\text {st }}$ scene showing Pavel Milyukov, Fedor Rodichev and others, and where the famous lawyer Vladimir Kuzmin-Karavayev urged "to pull the homeland away from those hands which are ready to throw the country in a whirlpool of a social revolution" ${ }^{11}$ ); the ministers who are discussing a tense situation of affairs and looking for an exit from the current situation at a meeting of the Council of Ministers, assuming mainly cruel methods, including the suppression of demonstrations by troops. It is evident that Dmitrii Sverchkov tried to show such a social diversity to portray how the whole society was entirely taken over by revolutionary events, and that they had no autonomous character at all, and were significant in causing important consequences for the whole country.

In addition, Sverchkov provided certain geographical coverage of the revolutionary situation. Along with St. Petersburg, there are other cities: scenes from the revolutionary life of Moscow, Kharkiv, Ekaterinoslav, Samara. Separate shots were supposed to show major historical documents of the time, for example, an extract from "The Financial Manifesto" of the St. Petersburg Soviet of Workers' Deputies, with an appeal to citizens to destroy the governmental public finances by the withdrawal of deposits from savings

9 Russian State Historical Archive (Российский государственный исторический архив. RSHA). F. 1093. Op. 1. D. 197. L. 2.

10 Ibidem. L. 6.

11 Ibidem. L. 15. 
$\operatorname{kass}^{12}$, or the decision of the commander of the St. Petersburg Military District to arrest members of the Executive Committee of the St. Petersburg Soviet during its meeting ${ }^{13}$. This inclusion of documents gave some reliability, a certain authority to an art film.

According to the scenario's introduction, Sverchkov filmed scenes in those places where the revolutionary events actually took place, and among the participants of a filmmaking proces there had to be also those who were participants of the described events of 1905, repeating, for instance, a scene "in front of the office of the operator what they did in 1905"14. Thus, the scriptwriter expected to remove not only art but, partly, documentary cinema. However, it is correct to note that all the participants of those events could hardly repeat with accuracy the actions in front of the camera since nearly 20 years had passed. They might forget specific details, meaning it did not correspond to what actually happened.

Also, we should pay some attention to the phrases and the dialogues of the film's heroes. For example, the speaker at a meeting of workers at the Obukhovski Plant, before elections to the Soviet in October 1905, relates the following: "To integrate all our fight against autocracy and capitalists, we will select deputies in the Working Soviet, they will gather together with deputies of other factories and plants and will give to our revolutionary movement organization and force ..." ${ }^{15}$. After this was accepted, Petr Zlydnev (his photo was to be shown in a frame) was the first to be selected as a deputy from the plant"

The small dialogues were conceived from such separate phrases. For instance, in the 40th scene, there is the chairman of the Council of Ministers, Count Sergey Vitte, presenting a report in the room of Emperor Nicholas II, and they have the following conversation:

“ - Sovereign, everywhere we have disorders... The state is in danger.

- What shall we do?

- Sign the manifesto on freedoms...

- Never.

- Your Majesty, a promise and a sign on a paper does not mean carrying out these freedoms in life...

- Prepare the project"16.

Some scenes were to demonstrate how representatives of different segments of the population join workers and support the revolutionary movement. There are bank employees, theater actors and railroad workers. For example, in the 27 th scene, the officer of the National Bank gets up and speaks to all attendees: "Really we will not join with the whole of Russia?" 17 , and after that a group of officers "is thrown by affairs, gather in small

\footnotetext{
12 Ibidem. L. 17.

13 Ibidem. L. 18.

14 Ibidem. L. 2.

15 Ibidem. L. 5.

16 Ibidem. L. 8.

17 Ibidem.
} 
groups and go to an exit", and the closing of a bank is the result. It continues by proving the general, nationwide character of the revolution, as gradually all segments of the country's population rise against the imperial government and autocracy.

The author's attention was focused not only on particular heroes or separate social strata but also on the masses who went onto the streets and joined demonstrations or strikes. The emergence of this image in the planned film was, perhaps, to emphasize how ordinary people made a massive protest to the tsar and his government, who were not ready to improve people's lives. A number of scenes describe episodes about the real power of the St. Petersburg Soviet, and the symbolic value for this is the ticket of the Soviet's deputy or the warrant of the Soviet signed by its chairman George Khrustalev (Khrustalev-Nossar), needed for the release of any member of the Soviet under guard or to make free from state duty the person who is necessary for the implementation of an order of the Soviet. Concerning this, it is possible to cite the episode in the courtroom: scenes 79-83 with the title "All Orders of the Soviet Are Executed ...". The worker gives to the chief judge the warrant of the Soviet with instruction "to make free from witness testimony the director of the Electricity Station for execution of the order of the Soviet to stop providing electricity in the post office building because of the post and cable strike which is taking place" ${ }^{\text {. }}$ The director of the Station left the courtroom with the worker without having executed his duty to give testimony. This shows to the viewer of the film the significant force and power of the St. Petersburg Soviet of Workers' Deputies in 1905 and underlines that it has more influence than such public institutions of power as a state court.

However, the film does not finish with the arrest of the Executive Committee of the St. Petersburg Soviet in December 1905. The final, $9^{\text {th }}$ part of the script is titled "Their destiny" and is devoted to the further activities of the members of the Executive Committee of the Soviet: Leon Trotsky, who is "at the Komintern meeting... among other leaders", Khrustalev (Khrustalev-Nossar, the chairman of the Soviet), "the head of hetman police" 19 at Pereyaslav in Ukraine, taken and shot by the Red Army. The grave of Petr Zlydnev, a member of Executive Committee of the Soviet who died between 1905 and 1917 while in exile in Chita, is shown separately. Dmitry Sverchkov, the scriptwriter, concludes this "gallery" of portraits while working at the National Commissariat of Means of Communication. It should be noted that, as a matter of common knowledge, the leader of the Bolsheviks, Vladimir Lenin, arrived in Russia and participated in a number of the events connected with the St. Petersburg Soviet. The $89^{\text {th }}$ scene concentrates on his speech at the meeting of the Executive Committee of the Soviet and, in particular, his appeal for the merging of all the Soviets of Russia, as well as for the proletariat to unite with the peasantry, army and fleet for the victory of a general revolt. The last four scenes of the film constitute an "Epilogue," opening with the following phrase: "The Soviets were crushed in 1905. They revived on the first day of the February Revolution 1917 and won in October $1917 " 20$. It was supposed to show a demonstration on the square that included

18 Ibidem. L. 14.

19 Ibidem. L. 20.

20 Ibidem. L. 21. 
the Tauride Palace, which was now the place for meetings of the Leningrad Soviet of the Workers' and Army's Deputies. Envisioned by the author, this showed the visual continuity of the Soviets of 1905 and 1917, the past and the present. The last scene (probably, with the same purpose) was supposed to show the members of the Leningrad Soviet, 1924 who had also been members of the St. Petersburg Soviet of 1905.

Summing up the results, it can be concluded that the film script "October revolution of 1905 and the First St. Petersburg Soviet of Workers' Deputies" of Dmitry Sverchkov, submitted for consideration by the film studio "Sevzapkino" in 1924, represented an attempt for a cinematic depictation of "the people's Soviets" 1905 and, most importantly, the portrayal of the St. Petersburg Soviet of Workers' Deputies in which Sverchkov took a direct part in its revolutionary activities. The history of the creation, activity and termination of the Soviet passes through all social and geographical panoramas of the revolutionary events described in the scenario. The people's power headed by the Soviet was to overturn a tsarist regime unable to make life better, and this is the main idea of Sverchkov's script. It is difficult to tell why the scenario was not turned into an actual film.

As far as is known, this plan of Dmitry Sverchkov to show the history of the Soviets of 1905 through cinema was subsequently realized with the author's participation: in 1930 there was the film of Noy Galkin, called "Two Forces" (also titled - "1905 /Barometer Shows a Storm"). Its plot was episodes showing the revolutionary events of 1905, including the creation of the Soviets in some cities and the revolutionary revolt at the boundary fortress Kushka (following the protest of the St. Petersburg Soviet against the carrying out of the death penalty for the Kushkinsky railroad employees who had participated in a strike). Unfortunately, it is not possible to assess its plot visually, since the film has been lost. Dmitry Sverchkov was the co-author of the scenario along with the director of the film, and with Mikhail Bleyman and Leonid Konstantinovsky also contributing. It should be stated that in the "Two Forces" Sverchkov's plan was partly realized. Such a conclusion can be made by analyzing the reviews of this film published in the Soviet press. In particular, Alexander Moskovsky, sceptically assessing the film, wrote in the magazine "Cinema and Life", that there are "also rooms of the St. Petersburg Soviet", but nothing can be seen, except (among other episodes) " $a$ 'state' type of worker in the St. Petersburg Soviet" ${ }^{\prime 2}$. It can be argued that Sverchkov, invited as the screenwriter and consultant, was one of the key participants for the reconstruction of the scenes connected with the St. Petersburg Soviet of Workers' Deputies in 1905. However, the film was not met with enthusiastic responses and was, subsequently, forgotten. Therefore the cinematic attempts of Sverchkov to keep the memory of the 1905 St. Petersburg Soviet came to an end without success.

21 MOSKOVSKY, Alexander: 1905 god na ekrane. In: Kino i zhizn', 1930, 36, p. 6. 
"Down with autocracy! Long live The Soviet!": the play "But Are Not Defeated! (1905)" (1931)

It is worth noting that Dmitry Sverchkov wanted to leave a testament to the 1905 St. Petersburg Soviet of Worker's Deputies not only in a cinema but also in the form of a theatrical play. Thus, in 1931 his play "But Are Not Defeated!" was published in the "Federation". The author was concerned with the necessity of developing a historicorevolutionary subject for Soviet dramatic art at the end of the 1920s/beginning of the 1930s, when it was popular to speak mostly about the socialist reconstruction and to write about collective farmers and industrial workers. At the evening meeting of the III Plenum of Vseroskomdram on the $8^{\text {th }}$ of June 1931, he said that a writer appealed to him to create a play about the revolutionary events of 1905 and create a plot to include "one intellectual, one worker and two women". However Sverchkov considered this a banality and urged colleagues "to capture the viewer by the development of a plot"22. He complained that for the Historico-Revolutionary Theater of Society of the Former Political Convicts there was no repertoire: “And historico-revolutionary subjects are very important and interesting, rich with plots [...] I ask [...] to provide historico-revolutionary plays, which are very, very necessary for our USSR"23. In this sense, Sverchkov, by writing a play about the 1905 events, was eager to become an example for Soviet playwrights.

The plot of the play "But Are Not Defeated!" is in many respects devoted to the creation and activity of the St. Petersburg Soviet of Workers' Deputies of 1905. Among characters, the reader encounters real heroes of that era, people such as Sergey Witte, Joseph Gessen, Konstantin Balmont, Pavel Milyukov and, of course, Vladimir Lenin. However, they are not so important for Sverchkov. His main characters are those who became the "makers of a history" in 1905: workers. Two of them are the Bolsheviks Vasily and Vera, and there were as well many different people not identified by name. The main idea of the author, perhaps, is that the Soviet was the real (not formal) public authority reflecting the interests of ordinary people.

The play opens with a scene set on the $14^{\text {th }}$ of October 1905 , in a steel foundry which is involved in a general strike. This shows strike events similar to the film script "October Revolution 1905..." This scene became a starting point for the plot's action. An important character is a worker called Vasily who states:

“Comrades! All factories, plants,

Gone on strike yesterday, decided

To call all other workers to fight

And to become under the management of the electoral committee.

We will call it the Soviet of Deputies. It is us who

22 Manuscript Department of Institute of World's Literature and Art of Russian Academy of Sciences (Otdel rukopisej Instituta mirovoj literatury i iskusstva RAN, MD IWLA RAS). F. 52. Op. 1. D. 4164. L. 76a. 
will connect together

And give unity and a force for a victory" ${ }^{24}$.

Workers remembered the victims of "Bloody Sunday" (the $9^{\text {th }}$ of January 1905) with a minute of silence. That was a tradition for many years. It was honouring the memory of the demonstrating workers who were shot while protesting their demands to the imperial power at the Winter Palace. These demands were not satisfied. It can be examined as a brotherly proletarian spirit, a solidarity of all workers. The worker Vasily urges all to elect deputies to the Soviet, and workers put forward four names - his own, Lebedev, Kurnosov and Mikhaylov. All of them are Bolsheviks who are standing up for the dictatorship of the proletariat against the tsar and the bourgeoisie. Meanwhile, of course, working deputies belonged to the RSDWP. Although not at all plants, many of them were not in any party and had a little understanding of the political parties of this era. Nevertheless, in reality, the authority of the Bolsheviks was strong among metalworkers in 1905 and later.

In addition, there is an anti-hero character called "Menshevik". He has no actual name and this hints at the author's position towards this character (most of the Bolsheviks, however, were in cooperation with the Mensheviks in 1905 and later for some time). In contrast to the Bolsheviks, "Menshevik" is against an armed revolt, and in favour of electing working deputies to a parliament:

"When they will appear in a large number, -

They will pass laws against the capital,

They will be accepted as the majority, - it's in the bag!"25.

Here, at a workers" meeting, we see an "ally" of "Menshevik", a man called "Unskilled worker". In the list of characters of the play, it is specified that he is from the peasantry and recently arrived to work at the plant. The "Unskilled worker" states that he dislikes a strike of railroad workers as it is a hindrance to peasants who want to take their products to a city sale. However a character, Vera, and other workers accuse him of calling to break the general revolt against the tsar and the bourgeois ("petty-bourgeois" as expressed by the terminology of the Soviet ideology after 1917). Thus, the heroes of events a priori are not the main heroes in the plot of the play, and they recede into the background of the stage.

The play continues with Sverchkov bringing to the stage, probably to provide a contrast, more revolutionary characters. Vera, having shown scepticism in relation to the "Unskilled worker", attracts the attention of Vasily by her suggestion that he enters their "committee", establishing the main romantic line of a young man and woman. Among other characters, Mikhaylov, who is one of the elected deputies, urges workers to expel from the plant the masters Migulin and Kartashev and also the engineer Tilmans. Work-

24 SVERCHKOV, Dmitry: No ne pobezhdeny (1905 god). Moscow: Federatsiya, 1931, p. 6.

25 Ibidem, 8. 
ers amicably support the idea: these men are taken, stacked in wheelbarrows with bags and rolled to the gate of the plant. Accompanying exclamations include "Down with autocracy! Long live the Soviet!".

Thus, Sverchkov, despite some exaggerations or simplifications, tried to demonstrate the people's authority of the elected Soviet of Workers' Deputies, an authority which grew as opposed to weak imperial autocracy that refused to resolve a worker's problems.

The next action of the play opens with a scene from the life of a theater in which "Hamlet" is being played. In time, a worker appears on the stage, interrupts a performance and suggests the actors go on a general strike. The performer of the role of Hamlet answers:

"We stop performing in the theater

Also we support the Soviet.

(To public) We announce

The Interval - until the falling of tsarism.

Down with autocracy!" 26 .

Surprisingly, representatives of the theatrical intellectuals really did partly support the Soviet, including its general strikes. One man, Yakov Vernstrem, who was present at the meetings of the Soviet in October 1905, later stated on one of his interrogations by police about the criminal case against the Soviet in March 1906: "From one of the meetings, according to the Khrustalev's proposal [George Khrustalev-Nossar, the chairman of the Soviet], deputations were sent for the closing of theaters [for the time of the strike]"27. Vernstrem also claimed that even one theater which, on assurance of Khrustalev-Nossar held a performance in favor of the strike, was closed by mistake. It is well known that the performance "Children of the Sun" (a play written by the famous social-democrat Maxim Gorky), which at that time was not subjected to censorship, was shown in the Theatre of the actress Vera Komissarzhevskaya on the $12^{\text {th }}$ of October 1905, and the actress supported the St. Petersburg Soviet of Workers' Deputies.

The image of the Chairman of the Soviet in the play is remarkable because he is named as the "Chairman" and not called by his name, George Khrustalev-Nossar, the lawyer famous for an interest in workers' problems and familiar to workers as a man who carried out propaganda among them. The absence of his name in the play can be explained by the subjectively negative attitude of Sverchkov towards Khrustalev-Nossar, who, according to the author, was weak-willed in his position, and, subsequently, departed from social-democracy in general and later assumed the right to be a creator of a "first Soviet"28. Moreover, Bolsheviks shot Hrustalyov-Nosar for anti-Soviet propaganda

26 Ibidem, 13.

27 State Archive of Russian Federation (Gosudarstvennyj archiv Rossijskoj Federacii, SA RF). F. 102. D. 7. 1905. Op. 202. D. 6409 t. 2. L. 228.

28 SVERCHKOV, Dmitry: G. S. Nosar-Khrustalev. Opyt politicheskoy biografii. Leningrad: Gosizdat, 1925, p. 31-32. 
in Pereyaslav in 1919. Therefore his name was deleted from the history of the revolutionary process and could hardly appear publicly in the early 1930s.

Nevertheless, the "Chairman" is not shown in the play as the «villain» of the revolution, since it would contradict the idea of the "people's Soviet", which always showed a chairman in contact with lay persons. Two examples are as follows: a worker comes to him holding a small knot with copper coins collected by other workers for arms to aid a general revolt; the deputation of workers of a plant asks the Chairman to accept a greeting as the sign of the accession of their enterprise to the Soviet. Even the wife of a shoemaker who drinks, spending all their money on alcohol, asks the Chairman to administer a divorce:

\author{
"Agree to divorce. \\ On a coffin of your service I will not forget, \\ I will pray for your health, \\ And ask God to give you the Kingdom of Heaven".
}

The Chairman, being a little been confused by the request, answers:

"What the hell! Well, alright, come to me
And bring the husband with you"29.

Sverchkov aims to show that the Soviet held the people's authority, moved towards the people's needs, while at the same time winning the fight against the imperial autocracy, and that the Soviet sought to solve the problems of the people by addressing them: city inhabitants "donated firewood, things, money" from the awareness of knowing what road it is better to go down because of a strike, and ask about the protection of their property ${ }^{30}$.

The $2^{\text {nd }}$ action of the play opens with a scene in a room of the Count Sergey Vitte, the Prime Minister of the imperial government. It shows that workers are not the only participants of the revolutionary events. And this, as well as in the film script "The October Revolution 1905..." (1924) is evidence of Sverchkov's intention to show a panorama of the whole society at the revolutionary moment, the all-embracing nature of the revolution constituting danger to those who were governors or people close to the head of the state. Count Vitte meets manufacturers, journalists and representatives of constitutional democrats (so-called "cadets"). The manufacturers, demanding support in view of workers' strikes and failure of production, are given this answer by Vitte:

"I will support you. If

Workers will make a further protest, -

29 SVERCHKOV, Dmitry: No ne pobezhdeny... Op. cit., p. 25.

30 GORIN, Pavel: Ocherki po istorii Sovetov rabochikh deputatov v 1905 g. 2-e izd. Moscow: Izdatelstvo Kommunisticheskoy Akademii, 1930, p. 249. 
We shall fire them, we shall close factories, plants,

Let proletarians will hunger" 31 .

The upset journalists, who were "loyal" to the authority, whose activity is affected by the Soviet in terms of the freedom of press state that the Soviet forces them to print its resolutions, but Vitte calmed them. Meanwhile, the Soviet issued "Izvestia", using a freedom of press announced by itself. After the journalists' exit, the third meeting with the Count takes place, involving Pavel Milyukov and a delegation of "cadets", who in 1905 supported the governmental policy on revolutionary organizations. It is known that "cadets" did not make such an open support of the tsar's power. The "union" of the liberal and government circles occurred as the author of the play showed. As a result of all three meetings, Vitte formulated a question to the government about the arrest of the Soviet of Workers' Deputies. All these scenes in the Count's office were necessary for Sverchkov to demonstrate how industrialists and the intellectuals were ready to cooperate with the state power in order to overcome the revolutionary chaos. To sum up, these heroes became enemies, opponents of real and truly great "heroes of the revolution": workers and proletarians. In addition, the famous poet Konstantin Balmont appears on stage and reads his new poem dedicated to an abstract worker, and which, according to a remark of a heroine called "Lady", replaced the initials "K. D." with "S. D.". That means sympathy to socialists (from the "cadets" to the social-democrats). Perhaps, in the words of this "Lady" (to whom, however, the author hardly takes a liking), there was a peculiar irony from Sverchkov for the "doubting" men of intellectuals who are changing sides (state power or revolutionary movement) depending on the present advantageous political position. According to the author, the intellectuals is not a good "ally" in the revolutionary struggle.

The definitive part in the play is taken by Vladimir Lenin, the leader of the Bolshevik party and the proletariat. This hero is not seen on the stage, but other heroes of the play speak about him, and perhaps it creates a certain aura of mystery around the person who began to be canonized by state power in the late 1920s. From the conversations of workers it is clear that they know about the party leader of the Bolsheviks. Vasily, admitting Vera to the party organization, tells her about Lenin:

"Almost at each meeting of the Soviet

He is there. Sits in a corner and writes something.

I will show you. He speaks,

That any concession to liberals

Will make us weaker..."32.

Vera asks whether she will hear his speech, and Vasily in reply assures her that it will happen. In reality, Lenin, at the beginning of November 1905, arrived in St. Petersburg,

31 SVERCHKOV, Dmitry: No ne pobezhdeny... Op. cit., p. 30.

32 Ibidem, p. 27. 
where he participated in the party work of the Bolsheviks. On the $13^{\text {th }}$ of November, he also made a speech at a meeting of the Soviet, the activities of which he had been watching since his arrival. Lenin's role as an observer is precious, while at the same time he published articles in which he considered the Soviets as the bodies of revolutionary power. On the other hand, the "remoteness" of Vladimir Lenin's image at the end of the 1920 s and beginning of the 1930s means it had an absolute inaccessibility. The conversation of two workers after the arrest of the St. Petersburg Soviet's Executive Committee shows one of them noticing that, despite being arrested, party figures remain safe, and "the Soviet is strong, but it cannot replace the Party", and this circumstance, according to this character, confirms Lenin's correctness. The interlocutor asked whether he was arrested, and the worker answers that Lenin was not but that he had disappeared, and he "will give a voice from far away, and we all shall hear it"33. According to Sverchkov, the huge force and authority of Lenin is absolute, and there is also evident a subjective desire of the author to honor with kind words the memory of the leader of the proletariat, who by the beginning of the 1930s had of course been dead for several years.

The struggle of political forces is visible not only from dialogues of high authorities and the public; it is also noticeable in a fermentation among ordinary people. The $3^{\text {rd }}$ section of the $2^{\text {nd }}$ action is one great representation of the collision of revolutionaries and the pro-monarchist "Black Hundreds" on a town square. The revolutionaries demonstrate, singing revolutionary songs: "The first rows of protesters with a red banner are shown. The policeman salutes a red banner" 34 . They are attacked by the "Black Hundreds", who are singing "Save, My God, your people," and this becomes mixed up with the revolutionary songs. A fight ensues between, on one side, the revolutionaries, supported by the working class and, on the other side, the pro-monarchists backed by troops. The revolutionaries retreat into the People's House, which is on the square, hanging out red banners, but the "Black Hundreds" with assistance from a policeman set fire to the house, and they triumph. Sverchkov with this scene showed the terrible force of revolutionary elements when people do not have sympathy for each other and are ready to kill for the sake of their own beliefs.

Dmitry Sverchkov was a supporter of realism and an opponent of dramatic art favouring bombastic characters. At the III Plenum of Vseroskomdram, on the $8^{\text {th }}$ of June 1931, he stated: "It is not necessary to be afraid of the truth, it is necessary to represent it in an installation that is right, to open a true entity of events, to unroll the internal content of the represented events and to draw from them right conclusions" 35 . In his play about the events of 1905, despite separate simplifications and what the author called "right installations" (for example the important role of Bolsheviks and V. I. Lenin), Sverchkov managed to show the controversial history of the Soviet: here can be found the "intrigues" of liberals and the government led by Vitte, the person interested in arresting the Soviet; the "Black Hundred" riots; an unsuccessful explosion of a train by two revolutionary workers; the

33 Ibidem, p. 46.

34 Ibidem, p. 35.

35 Manuscript Department of Institute of World's Literature and Art of Russian Academy of Sciences (Otdel rukopisej Instituta mirovoj literatury i iskusstva RAN, MD IWLA RAS). F. 52. Op. 1. D. 4164. L. 77. 
jeers of imperial officers towards Vera on the barricades; and, finally, a defeat of the "people‘s" Soviet of 1905, its capitulation to tsarist imperial Russia.

This historical moment is, however, contradictory: workers failed, but there was also hope for new revolutionary fulfillments. Sverchkov, a contemporary of, and participant in, the First Russian Revolution and a member of the Executive Committee of the St. Petersburg Soviet, emphasizes through the plot of his play, and in particular, the final scene, that the idea of "the people's Soviet" did not leave the minds of revolutionaries forever: the worker Vasily, close to his lovely Vera on the barricades, when questioned by one of the combatants if they are broken, answers:

\footnotetext{
"But we are not defeated. Let's go underground again,

Let's remember our experience of street fighting,

Let's become organized, we shall strengthen a group and we shall lead

Work among the army, among peasants.

Then - on to a new fight. Let's recreate the Soviets

And we shall win!"36.
}

$* * *$

In conclusion, Dmitry Sverchkov's film script "October Revolution of 1905 and the First St. Petersburg Soviet of Workers' Deputies" submitted for the consideration by the film studio "Sevzapkino" in 1924, like the play "But Are Not Defeated! (1905)" published in 1931, was an attempt to represent in cinematic/dramatic terms a portrait of "the people's Soviets" of 1905 and, primarily, the St. Petersburg Soviet of Workers' Deputies in which Sverchkov took a direct part. The history of the creation, activity and termination of the Soviet connects to all social and geographical panoramas of the revolutionary events described in the scenario. The masses of the people, whose questions were ignored by the tsar's power, were, with further organization from the Soviet, ready to overthrow the tsar and his government, and for ordinary people, there was a correct way of proceeding: to construct the people's revolutionary power in place of the tsar's autocratic and weak government. That is, perhaps, the main idea of Sverchkov's script. It is difficult to know why the scenario was not turned into a film. The writer sincerely aspired to keep the memory of a milestone historical event: the emergence of the "prototype" for the Petrograd Soviet of Workers' and Soldiers' Deputies of 1917, which was formed after the February Revolution and later became the Bolshevist's Leningrad Soviet. Certainly, it is correct to state that this literary and published activity of Sverchkov was within the ideological and political background of life in the USSR during the 1920s and 1930s.

It seems that Dmitry Sverchkov underlined in both his scenario and play the idea that the First Russian Revolution was the event which captured every strata of society and resulted from the crisis of autocratic power, which failed the interests of workers, peasants, soldiers, that is, the people. He illustrated this with the actions of authorities,

36 SVERCHKOV, Dmitry: No ne pobezhdeny... Op. cit., p. 62. 
intellectuals, and the people. The author paid particular attention to the emergence, activity, and termination of the St. Petersburg Soviet of Workers' Deputies, since he was an eyewitness and participant of the related events. He emphasized the people's activity of the Soviet, its broad authority in the eyes of ordinary people and even the public authorities who "were afraid" of it. Sverchkov also showed the downfall of the Soviet, the victory of the tsarist imperial power which, in general, defeated the first revolution. This was, though, from perspectives of the 1920s and the author also emphasized the temporary nature of this "victory". The message at the end of both works was that the power of the Soviets would lead to their emergence on the historical stage, which of course was to occur in 1917. It was important for Sverchkov to build this line of continuity and to emphasize the historical value of the St. Petersburg Soviet of Workers' Deputies of 1905.

There were sceptical reviews by critics and colleagues to Sverchkov's projects, which were not fully realized (as, for example, the film script "October Revolution 1905..." in 1924). There also existed ideological circumstances: the friendship and correspondence with Leon Trotsky, and the uncertain political position (between the Bolsheviks and the Mensheviks) during the period between revolutions, 1905-1917. These circumstances led to Dmitry Sverchkov leaving the historical stage, as a political opponent of power, in the 1930s. After his rehabilitation in the 1950 s, he was forgotten along with his published works and literary heritage. He does, however, deserve at least a certain interest from literary critics and researchers of events in the history of Russia at the beginning (and even the first third) of the twentieth century.

\section{Sources}

Manuscript Department of Institute of World's Literature and Art of Russian Academy of Sciences (Otdel rukopisej Instituta mirovoj literatury i iskusstva RAN. MD IWLA RAS). F. 52. Op. 1. D. 4164.

Russian State Historical Archive (Российский государственный исторический архив. RSHA). F. 1093. Op. 1. D. 197.

State Archive of Russian Federation (Gosudarstvennyj archiv Rossijskoj Federacii. SA RF). F. 102. D. 7. 1905. Op. 202. D. 6409 t. 2.

SVERCHKOV, Dmitry: No ne pobezhdeny (1905 god). Moscow: Federatsiya, 1931.

\section{Literature}

ALATORTSEVA, Alevtina: Sovetskaya istoricheskaya periodika 1917 - seredina 1930-kh godov. Moscow: Nauka, 1989.

FEVRALSKY, Alexander: Vstrechi s Mayakovskim. Moscow: Sovetskaya Rossiya, 1971.

GORIN, Pavel: Ocherki po istorii Sovetov rabochikh deputatov v 1905 g. 2-e izd. Moscow: Izdatelstvo Kommunisticheskoy Akademii, 1930. 
KAZANCHI, Aslan: Grazhdanskaya voyna na Severnom Kavkaze glazami ochevidtsa (Po materialam Tsentra dokumentatsii noveyshey istorii Krasnodarskogo kraya (TsDNIKK)). In: Rossiya glazami memuaristov: Analiz neizvestnykh i maloizvestnykh vospominaniy. Materialy 36-y Vserossiyskoy zaochnoy nauchnoy konferentsii. Saint-Petersburg: Nestor, 2004.

MAYAKOVSKY, Vladimir: Polnoye sobraniye sochineniy. T. 12. Moscow: Goslitizdat, 1959.

MOSKOVSKY, Alexander: 1905 god na ekrane. In: Kino i zhizn, 1930, №36.

SVERCHKOV, Dmitry: On the transport. In: O F. E. Dzerzhinskom. Vospominaniya. Stati. Ocherki souremennikov. Moscow: Politizdat, 1977, p. 191-195.

SHALAMOV, Varlam: Vospominaniya. In: SHALAMOV, Varlam: Neskolko moikh zhizney. Vospominaniya. Zapisnyye knizhki. Perepiska. Sledstvennyye dela. Moscow: Eksmo, 2009.

SVERCHKOV, Dmitry: Autobiography. In: Deyateli SSSR i revolyutsionnogo dvizheniya Rossii. Entsiklopedicheskiy slovar Granat. Moscow: Kniga, 1989.

SVERCHKOV, Dmitry: G. S. Nosar-Khrustalev. Opyt politicheskoy biografii. Leningrad: Gosizdat, 1925. Sverchkov Dmitry Fedorovich. In: Stsenaristy sovetskogo khudozhestvennogo kino. 1917-1967. Spravochnik. Moscow: Iskusstvo, 1973.

\section{Ilya Nikolaevich Strekalov}

Department of the Russian History of the XIXth - the beginning of the XXth century

The Lomonosov Moscow State University

Lomonosovsky prospect 27/4, 119192 Moscow, Russia

strek93@mail.ru 
